\title{
Proses Resiliensi Jurnalis Radio 68H Pasca Bom Buku 15 Maret 2011
}

\author{
Gita Widya Laksmini Soerjoatmodjo \\ Program Studi Psikologi, Universitas Pembangunan Jaya, \\ Kampus UPJ I Jl. Boulevard Bintaro Sektor VII \\ Bintaro Jaya Tangerang 15224 Banten \\ gita.soerjoatmodjo@upj.ac.id / gita.soerjoatmodjo@gmail.com
}

\begin{abstract}
On March 15, 2011, a bomb glued to a book and received by 68H News Agency (68H) exploded, causing severe injury to a police officer on duty. Yet the journalists resumed work, advocated their stance for freedom of expression and continued broadcasting. Resilience, a successful adaptation to adversity to "bounce back" is shown in this incident by $68 \mathrm{H}$ journalists and is relevant to any journalists working in Indonesia as one of the five deadliest countries in 2010 according to Committee to Protect Journalists. Using semi-structured interview and 'resilience-as-a-process' perspective, this research describes how $68 H$ journalists undergo their process, what occurs as they become resilient, resources they utilize, and consequent changes in their ability to maintain their resilience in the future. Results show that regrouping and capacity building are pivotal in the stages of their resilience process. It concludes that collective identity and leadership, in perceiving 'us'versus 'them' and in promoting values important to them, as well as social supports and shared experiences of past successes, are main resources of their resilience. Lessons learned from their error of judgement of threat assessment leads to changed attitude and security reinforcement that contribute to their future resilience.
\end{abstract}

Keywords: resilience, resilience-as-a-process, journalists, community, bomb

\begin{abstract}
Abstrak-Pada tanggal 15 Maret 2011, sebuah bom yang direkatkan dalam sebuah buku diterima oleh Kantor Berita $68 \mathrm{H}$ kemudian meledak, menyebabkan cedera parah pada petugas kepolisian yang sedang bertugas. Meskipun demikian, para jurnalis terus bekerja dan menyuarakan dukungan mereka atas kebebasan berekspresi. Resiliensi yakni adaptasi yang berhasil dalam mengatasi tantangan, tampak pada bagaimana jurnalis $68 \mathrm{H}$ berhasil "melenting kembali." Bagi jurnalis yang bekerja di Indonesia, yakni satu dari lima negara yang paling mematikan di tahun 2010 menurut Committee to Protect Journalists, resiliensi menjadi penting untuk dipelajari. Menggunakan wawancara semi-terstruktur dan perspektif 'resiliensi sebagai proses', penelitian ini menggambarkan bagaimana jurnalis $68 \mathrm{H}$ menjalankan proses tersebut, sumber daya
\end{abstract}


yang mereka gunakan serta konsekuensi pada kemampuan mereka untuk mempertahankan resiliensi di masa mendatang. Hasil penelitian menunjukkan bahwa penguatan kelompok dan peningkatan kapasitas penting dalam tahap-tahap proses resiliensi mereka. Disimpulkan bahwa identitas kolektif dan kepemimpinan dalam mempresepsikan 'kita' versus 'mereka' dan dalam mempromosikan nilai-nilai yang penting bagi mereka juga dukungan sosial serta pengalaman keberhasilan bersama di masa lalu, merupakan sumber-sumber daya utama resiliensi. Hikmah ajar dari kekeliruan menimbang ancaman berkontribusi pada perubahan sikap dan peningkatan keamanan demi mempertahankan resiliensi di masa mendatang.

Kata kunci: resiliensi; resiliensi-sebagai-proses; jurnalis; komunitas; bom

\section{PENDAHULUAN}

Resiliensi (resilience), menurut Reich, Zaustra \& Hall (2010), merupakan adaptasi yang berhasil dalam menghadapi tantangan (adversity), kemampuan untuk bangkit melampaui situasi yang sulit, untuk pulih dari kemunduran, untuk terus maju dengan optimisme dan rasa percaya diri di tengah-tengah menghadapi tantangan atau dengan kata lain, kemampuan untuk "melenting kembali" ("bounce back").

Reich, Zaustra \& Hall (2010) menjelaskan lebih lanjut bahwa konsep resiliensi ini lahir dari pengamatan terhadap reaksi-reaksi berbagai individu ketika menghadapi tantangan. Beberapa orang memunculkan gejalagejala psikopatologis berat setelah menghadapi tantangan, tetapi sebagian lainnya justru mampu beradaptasi dengan baik dan memetik hikmah berkat ketangguhan akibat pengalaman tersebut.

Dari berbagai perspektif, terdapat sudut pandang yang melihat 'resiliensi-sebagai-proses' (resilienceas-process) yang digambarkan oleh McMahon \& McLellan dalam Gow \& Patton (2008) sebagai proses yang berlangsung pada saat individu bertumbuh menjadi resilien. Hal ini mencakup cara memanfaatkan sumber daya (resources) serta perubahan yang terjadi terhadap kemampuan mereka mengatasi tantangan.

Sudut pandang ini berbeda dengan 'resiliensi sebagai product' (resilience-as-product) yang melihat resiliensi sebagai sesuatu yang dimiliki atau tidak dimiliki oleh seseorang. McMahon \& McLellan (2008) melihat resiliensi-sebagai-proses dan memaknai resiliensi sebagai interaksi yang kompleks, dinamis dan sistematis dari proses pertumbuhan yang berlangsung dalam konteks tertentu.

Bagi mereka yang mengemban profesi jurnalis, resiliensi merupakan hal yang penting. Sementara orang lain berlari menghindari bencana, jurnalis justru bergegas menghampiri demi mendapatkan berita dan menempatkan diri mereka dalam situasi-situasi yang berpotensi menyebabkan trauma. Tak heran jika McMahon \& McLelland menyimpulkan bahwa jurnalis adalah kelompok pekerja yang berrisiko (at-risk).

Di Indonesia, tantangan tak dapat dipisahkan dari sejarah profesi tersebut. Sebelum era Reformasi 1998, tantangan datang dalam bentuk pembatasan politik berupa pencabutan izin penerbitan oleh negara (Hill, 2011). Di era Reformasi, jurnalis terseret-seret dalam konflik antarkelompok berbasis agama di berbagai tempat di Indonesia. Menurut Committee to Protect Journalists, tahun 2010 Indonesia menjadi satu dari 5 negara paling mematikan bagi jurnalis. Pada tahun yang sama, Reporters Without Borders mendudukkan Indonesia di peringkat 117 dari 178 negara dalam indeks kebebasan pers. Juga di tahun yang sama, Aliansi Jurnalis Independen mencatat sedikitnya 46 peristiwa kekerasan yang menimpa jurnalis dalam bentuk intimidasi, serangan verbal, vandalisme, pelarangan peliputan, upaya menghalang-halangi reportase, serangan fisik, pembunuhan dan kematian misterius. 
Bagi kebanyakan orang, pengalaman menghadapi tantangan seperti di atas dapat berdampak psikologis negatif. Namun hanya 26,19 persen dari 168 jurnalis yang diteliti oleh Yayasan Pulih (Pikiran Rakyat, Liput Konflik Berpotensi Trauma, 27 Februari 2011) menyadari dampak dari pengalaman menghadapi tantangan dalam sepanjang perjalanan profesional mereka. Menurut Feinstein (2006), tak hanya organisasi media yang abai dalam memperhatikan kesejahteraan psikologis para jurnalis mereka, tetapi para peneliti di bidang trauma pun belum banyak menaruh perhatian tentang hal ini. Coté \& Simpson (2000) juga menyebut bahwa sekalipun pengalaman jurnalis menghadapi gejala trauma cukup banyak didokumentasikan, belum ada kajian sistematis yang mendalami hal tersebut.

Khusus untuk jurnalis Radio 68H, tantangan merupakan bagian dari keseharian. Radio 68H didirikan di Komunitas Utan Kayu, Jalan Utan Kayu, di Jakarta pada tanggal 29 April 1999 oleh sejumlah aktivis dan jurnalis dengan tujuan mendukung demokrasi. Radio dipilih karena harga pesawat radio relatif terjangkau sehingga memungkinkan semua orang, termasuk yang buta huruf, untuk mengakses informasi.

Saat ini, Radio $68 \mathrm{H}$ memiliki sekitar 50 jurnalis di Jakarta, 100 koresponden di berbagai daerah di Indonesia termasuk 30 kontributor di Asia yang menyuplai program berita melalui jejaring satelit dan Internet ke lebih dari 750 stasiun radio dan menjangkau sekitar 22 juta pendengar (Situs Utan Kayu diakses 17 Mei 2011 dari www.utankayu.org.

Selama 14 tahun beroperasi, Radio 68H menghadapi sejumlah tantangan. Tanggal 5 Agustus 2005, Front Pembela Islam (FPI) melancarkan serangan terhadap Radio 68H. Hal ini karena Radio 68H dianggap sebagai corong liberalisme dan sekularisme yang dikedepankan oleh Jaringan Islam Liberal (JIL) yang juga berlokasi di komunitas yang sama (The Jakarta Post (2005) JIL, hard-liners sidestep confrontation. Terbit on 6 Agustus 2011).

Sedangkan di tanggal 15 Maret 2011, sekitar pukul 13: 00 WIB, paket berisi buku untuk Ulil Absar Abdala dari JIL diterima oleh resepsionis yang menemukan ada sejumlah kabel melekat di buku. Paket tersebut cepat-cepat dibawa ke lapangan parkir dan polisi langsung dihubungi. Sekitar pukul 16:00 WIB, lapangan parkir Radio $68 \mathrm{H}$ sesak dengan jurnalis dan petugas kepolisian serta orang-orang yang menonton. Polisi mencoba menjinakkan bom dengan menyiram buku menggunakan air dari selang. Tak lama kemudian bom meledak, orang-orang berteriak, "Ada bom! Ada bom meledak!" Video liputan peristiwa ledakan bom buku ini dapat dilihat di Bambits378.(2011, 16 Maret). Bom buku utan kayu Jakarta [Berkas video]. Diunduh pada tanggal 18 Mei 2011 dari http://www.youtube.com/watch?v=1OL9iCoM2vg\&feature=related.

Jurnalis Radio $68 \mathrm{H}$, masih dengan serpihan debu di rambut akibat ledakan, dari sekitar satu meter dari lokasi, langsung memberikan laporan pandangan mata melalui acara Buletin Sore yang tengah mengudara saat itu lewat telepon genggam. Sekitar satu jam setelah ledakan, Radio 68H menggelar konferensi pers menyatakan sikap mereka mempertahankan kebebasan berekspresi dan terus beroperasi tanpa berhenti sejenak pun (The Jakarta Post. Utan Kayu Community Condemns Bombing. Terbit 15 Maret 2011).

Tulisan ini dimaksudkan untuk mendeskripsikan proses resiliensi yang dijalani oleh sejumlah jurnalis $68 \mathrm{H}$ pasca bom buku dalam menyesuaikan diri tatkala mengatasi tantangan. Proses ini mencakup cara mereka menggunakan berbagai sumber daya dalam upaya mengatasi tantangan dan perubahan perilaku agar tetap resilien di masa mendatang. Penelitian ini memandang jurnalis $68 \mathrm{H}$ sebagai anggota komunitas, yang memiliki latar belakang dan nilai yang sama serta terikat tak hanya oleh wilayah geografis mereka tetapi juga oleh ruang konseptual (Hall \& Zaustra dalam Reich, Zaustra \& Hall, 2010).

Yang dimaksud dengan tantangan (adversity) dalam penelitian ini adalah peristiwa hidup negatif yang secara statistik terkait dengan berbagai kesulitan penyesuaian diri (Schilling, 2008). Hal ini didefinisikan secara 
operasional sebagai peristiwa ledakan bom buku tanggal 15 Maret 2011. Penelitian ini juga menggunakan definisi Goldstein \& Brook (2006) tentang penyesuaian diri yang berhasil (successful adaptation) dalam menghadapi tantangan. Definisi ini dijelaskan secara operasional dalam penelitian ini sebagai kemampuan para jurnalis $68 \mathrm{H}$ dalam menjalankan tugas-tugas jurnalistik memproduksi berita tanpa ditandai responrespon yang 'melumpuhkan' kemampuan tersebut.

\section{Pertanyaan Penelitian}

Pertanyaan penelitian ini adalah sebagai berikut: pasca peristiwa ledakan bom buku 15 Maret 2011, bagaimana jurnalis-jurnalis $68 \mathrm{H}$ menjalani tahap-tahap dalam proses resiliensi, sumber-sumber daya apa saja yang mereka gunakan dalam proses tersebut, dan perubahan-perubahan perilaku apa saja yang terjadi akibat pengalaman tersebut yang berdampak pada kemampuan mereka untuk menjadi resilien di masa mendatang?

\section{Tujuan Penelitian}

Tujuan dari penelitian ini adalah untuk memotret deskripsi proses resiliensi pada jurnalis $68 \mathrm{H}$, sumber daya yang mereka gunakan di sepanjang proses resiliensi tersebut serta perubahan perilaku apa saja yang terjadi pada mereka akibat dari pengalaman menghadapi ledakan bom buku. Penelitian ini diharapkan dapat memberikan kontribusi pada pengembangan lebih jauh terhadap pemahaman tentang resiliensi terutama dari kelompok profesi jurnalis. Hal ini karena konsep resiliensi relevan dengan kerja jurnalis sehari-hari, terutama jurnalis di Indonesia.

\section{METODE}

\section{Partisipan}

Partisipan penelitian ini terdiri dari jurnalis $68 \mathrm{H}$ laki-laki dan perempuan berkebangsaan Indonesia maupun asing. Karakteristik partisipan adalah mereka yang mengalami langsung peristiwa ledakan bom buku pada tanggal 15 Maret 2011. Adapun teknik pengambilan subjek penelitian ini dilakukan dengan cara bola salju (snowballing).

\section{Desain}

Desain penelitian ini adalah penelitian kualitatif dengan menggunakan wawancara semi-terstruktur (semi-structured interview) untuk mengambil data. Hal ini karena penelitian bertujuan untuk memotret proses sebagaimana dielaborasi oleh subjek penelitian dalam proses wawancara.

\section{Prosedur}

Pertama-tama, peneliti menyusun daftar pertanyaan wawancara dengan berkonsultasi dengan pakar dari Yayasan Pulih yang menguasai isu trauma terkait dengan jurnalisme. Daftar pertanyaan berikut lembar konfirmasi kesediaan (informed consent) diajukan kepada partisipan dari Radio $68 \mathrm{H}$ dan proses wawancara berlangsung pada bulan Juni-Juli 2011. 
Wawancara yang berlangsung kurang lebih 45 sampai 120 menit kemudian ditranskripsi untuk dianalisis berdasarkan tiga kategori berdasarkan perspektif resiliensi-sebagai-proses yaitu tahap-tahap terjadinya resiliensi, sumber daya dan perubahan perilaku pasca bom buku. Dalam prosesnya, penulis menyadari bahwa latar belakang pribadinya sebagai jurnalis dan aktivis hak asasi manusia memberikan sensitivitas dalam memahami isu ini tetapi juga membuka peluang terjadinya bias pribadi. Hal ini diatasi dengan melalui kajian para rekan (peer review) guna melibatkan masukan dari kolega.

Peneliti menyadari bahwa tantangan seperti menghadapi ledakan bom berpotensi mengakibatkan trauma. Oleh karena itu, peneliti memberikan buku-buku tentang Post Traumatic Stress Disorder (PTSD) yang diterbitkan oleh Yayasan Pulih dan Dart Center for Journalism and Trauma untuk dijadikan referensi oleh Radio 68H. Peneliti juga memberikan kontak kepada Yayasan Pulih apabila ada pihak-pihak dari Radio $68 \mathrm{H}$ yang membutuhkan layanan pasca trauma. Hasil penelitian ini pun dikonsultasikan juga dengan pakar dari Yayasan Pulih.

\section{Teknik Analisis}

Teknik analisis yang digunakan dalam penelitian ini adalah coding di mana transkripsi dikaji secara sistematis dengan open coding untuk melihat tema-tema utama dari hasil wawancara, axial coding di mana peneliti menyusun tema tersebut secara sistematis dengan memperhatikan kronologi dan hubungan sebab akibat, yang diakhiri dengan selective coding di mana peneliti mengidentifikasi dan memilih sejumlah kutipan yang paling mendukung tema-tema utama tersebut.

\section{ANALISIS \& HASIL}

\section{Profil Subjek}

Subjek penelitian adalah 5 orang jurnalis Radio $68 \mathrm{H}-4$ orang berkewarganegaraan Indonesia dan 1 orang berkewarganegaraan Australia yang sudah bertahun-tahun tinggal di Indonesia dan mampu berbahasa Indonesia dengan lancar. Kelima subjek ini diperoleh melalui proses bola salju (snowballing) di mana partisipan yang satu merekomendasikan partisipan yang lain karena sama-sama mengalami peristiwa ledakan buku pada tanggal 15 Maret 2011, memiliki kemampuan mendeskripsikan pengalaman mereka secara terperinci, serta mewakili sudut pandang beragam. Seluruh partisipan penelitian ini telah bekerja sebagai jurnalis untuk Radio $68 \mathrm{H}$ selama lebih dari 1 tahun. Adapun subjek penelitian ini dirangkum pada Tabel 1 berikut ini.

Tabel 1. Subjek Penelitian

\begin{tabular}{llllll}
\hline No & Inisial & Usia & Jenis Kelamin & \multicolumn{1}{c}{ Posisi } & Kewarganegaraan \\
\hline 1 & AW & 34 & Laki-laki & Jurnalis dan produser program & Indonesia \\
2 & CD & 33 & Perempuan & Jurnalis dan produser program & Indonesia \\
3 & RH & 31 & Perempuan & Jurnalis dan produser program & Australia \\
4 & HH & 47 & Laki-laki & Redaktur & Indonesia \\
5 & SO & 47 & Laki-laki & Pemimpin Redaksi & Indonesia \\
\hline
\end{tabular}




\section{Kronologi Peristiwa}

Secara kronologis, berikut urut-urutan peristiwa yang menggambarkan proses resiliensi jurnalis $68 \mathrm{H}$. Hari Selasa, 15 Maret 2011 sekitar pukul 13.00, paket berisi bom tiba di Komunitas Utan Kayu. Paket ini diterima oleh resepsionis JIL. Sekitar pukul 14.00, personil JIL membuka paket dan menemukan buku dengan surat ditujukan kepada Ulil Absar Abdala. Ketika membuka paket, personil JIL melihat sejumlah kabel melekat di buku tersebut. Ia bawa paket tersebut cepat-cepat ke lapangan parkir. Polisi langsung dihubungi dan segera menuju Utan Kayu.

Kabar ini tersebar ke seluruh personil $68 \mathrm{H}$. AH dan CD menerima berita lewat fasilitas komunikasi internal kantor sedangkan $\mathrm{HH}$ dan SO menerimanya lewat pesan teks singkat. Seorang reporter dikirim untuk mewawancarai para saksi mata dan mengambil foto sehingga $\mathrm{CD}$ bisa mengunggah informasi tersebut ke situs Radio $68 \mathrm{H}$.

Sekitar pukul 16.00, HH dan SO menuju lapangan parkir yang sudah sesak dengan orang-orang menonton, para jurnalis dari berbagai media serta petugas kepolisian. SO menjelaskan kepada RH bahwa situasi ini terjadi karena ada pihak yang mencoba mengganggu kerja mereka. CD datang ke lapangan parkir, kemudian berjongkok di bawah garis polisi untuk mengambil foto tentang cara petugas polisi menjinakkan bom dengan menyirami buku dengan air yang dikucurkan dari selang. Tak lama kemudian bom yang melekat di dalam buku pun meledak.

AW berada di studio lantai dua memandu acara Buletin Sore dan mengira suara ledakan keras tersebut adalah bunyi petasan. Di lantai parkir, $\mathrm{CD}$ terjerembab akibat dorongan daya ledakan dan serpihan abu bom berhamburan memenuhi helai-helai rambutnya. Orang-orang berteriak, "Ada bom! Ada bom meledak!" Yang lain menjerit, "Tangannya kena!” Beberapa orang panik begitu menyadari bahwa tangan petugas polisi hancur berkeping-keping, termasuk RH yang berteriak-teriak, "Where's the ambulance?” (“Di mana ambulans?”). Mereka saling memastikan keselamatan sesama rekan dan salah satu dari mereka bertanya pada CD, "Elu ngga apa-apa? " CD mengangguk mengiyakan.

Dalam hitungan detik, CD langsung menghubungi telepon genggam AW dan berteriak dari ujung telepon, "Gue laporan live!" AW langsung mematikan telepon genggam, menyambar telepon studio lalu menghubungi CD kembali sehingga bisa menyiarkan laporan langsung dari tempat kejadian dalam acara Buletin Sore yang tengah mengudara saat itu. CD menyampaikan reportase pandangan mata sekitar 1 meter dari lokasi ledakan dan memberikan gambaran terkini tentang situasi yang sedang berlangsung. Beberapa saat setelah selesai melaporkan, sebuah stasiun televisi swasta menelepon CD lewat telepon genggamnya dan ia pun melaporkan pandangan sebagai saksi mata tentang proses evakuasi petugas polisi yang cedera menuju rumah sakit.

AW segera turun ke lantai belakang untuk melihat tempat kejadian setelah Buletin Sore tuntas. Saat itu, suami CD, yang juga jurnalis Green Radio datang untuk memastikan bahwa CD dalam keadaan selamat. RH sedang menghubungi suaminya lewat telepon sambil menangis terisak-isak. Di saat yang sama HH dan SO berdiskusi dengan perwakilan dari sejumlah organisasi yang bertempat di komunitas tersebut tentang langkah yang akan mereka ambil selanjutnya. Diputuskan bahwa mereka segera mengadakan konferensi pers.

HH mengundang para jurnalis yang sudah ada di lokasi dan mengadakan konferensi pers sekitar pukul 5 sore selama kurang lebih 10 menit. Dalam konferensi pers tersebut, SO menyatakan bahwa mereka akan tetap bertahan mempertahankan kebebasan berekspresi. Dari lokasi konferensi pers, CD melaporkan perkembangan terkini lewat Twitter dari telepon genggamnya. 
Setelah konferensi pers selesai, HH dan SO kembali berbincang-bincang dengan para awak pers. CD kembali ke meja kerjanya untuk menenangkan diri dan segera menyusun rancangan artikel Tajuk untuk diudarakan esok hari sebagai tanggapan terhadap peristiwa ledakan tersebut sambil meneruskan hasil foto jepretannya ke berbagai media melalui surat elektronik. Di luar kantor, para polisi menginterograsi para kolega.

Malam itu juga, SO menghubungi seorang teman penasehat keamanan dari Greenpeace Australia untuk memberikan pelatihan keamanan bagi $68 \mathrm{H}$, kemudian ia pulang ke rumah. CD dan suaminya pulang sekitar pukul 22.00. HH memilih tetap di kantor bersama-sama dengan para kolega jurnalis yang dijadwalkan kerja malam sebagai bentuk dukungan pada mereka dan agar bisa berdiskusi dengan mereka tentang langkahlangkah yang perlu dilakukan selanjutnya.

Rabu 16 Maret 2011, para personil 68H maupun dari organisasi-organisasi lain di Utan Kayu datang kembali ke kantor yang dijaga ketat oleh polisi. Setelah melalui pemeriksaan keamanan, HH dan SO mengarahkan mereka menuju ruang rapat. $\mathrm{CD}, \mathrm{AW}$ dan $\mathrm{RH}$ juga ada di ruang rapat tersebut bersama-sama dengan yang lain.

SO menyampaikan bahwa bom kemarin memperkuat kesimpulan bahwa hal yang mereka yakini, yakni kebebasan berekspresi, adalah benar dan layak untuk diperjuangkan. Ia menyampaikan bahwa merasa takut adalah hal yang bisa dipahami, tetapi semua orang di komunitas ini harus tetap bekerja karena, jika tidak, para penyerang tersebutlah yang menang. HH kemudian menambahkan penjelasan mengenai langkahlangkah yang perlu diambil setelah peristiwa ini, termasuk memperbaiki keamanan. Ia juga membumbui kata-katanya dengan humor di sana-sini. Setelah bertukar informasi tentang kejadian kemarin, HH kemudian membagikan penugasan, termasuk menunjuk AW sebagai juru bicara media.

Ketegangan pun menurun dan orang-orang mulai dapat bertukar kelakar, tertawa dan saling memeluk. Kemudian CD dan RH kembali ke pekerjaan jurnalistik mereka. RH mewawancarai CD untuk program Asia Calling tentang peristiwa tersebut. AW melayani permintaan wawancara dari berbagai media dan menangani urusan terkait dengan investigasi polisi, bersama-sama $\mathrm{HH}$ dan SO yang juga berhadapan dengan para pemangku kepentingan lainnya. Semua kembali bekerja seperti biasa.

Jumat, 18 Maret 2011, penasihat keamanan dari Greenpeace Australia datang dan memberikan pelatihan, termasuk cara mengidentifikasi paket mencurigakan, menjawab ancaman bom lewat telepon dan melaksanakan evakuasi. SO, HH, AW, CD dan RH berpartisipasi dalam pelatihan ini.

Di sore hari, sebuah paket datang dan memicu tanda peringatan setelah diperiksa menggunakan detektor metal. Pasukan Gegana dari Kepolisian datang segera dan menghancurkan paket tersebut. Kedatangan paket tersebut mengganggu jalannya pelatihan, namun memunculkan berbagai kesalahan yang muncul dalam merespon ancaman. Radio 68H membentuk Crisis Management Team (CMT) di hari yang sama.

Hari Sabtu tanggal 19 Maret 2011, pintu keluar jalan belakang dibangun. Sejumlah pengeras suara ditempatkan di sudut kantor untuk memudahkan penyampaian pengumuman. Lahan kosong seberang jalan disewa sebagai lapangan parkir tambahan agar ruang gerak seputar kantor lebih leluasa dan memudahkan evakuasi. Standar prosedur pelaksanaan terkait penanganan kondisi darurat disiapkan dan latihan tanggap darurat dijalankan. Penjaga keamanan berjaga di pintu masuk dan mengecek isi tas serta menukar kartu tanda pengenal dari pengunjung dengan tanda pas khusus. Radio $68 \mathrm{H}$ tetap mempertahankan posisi editorial mereka, yakni mempromosikan kebebasan berekspresi sampai saat ini.

Bagian di bawah ini memuat temuan-temuan yang diperoleh melalui penelitian berdasarkan tiga tema besar yaitu resiliensi sebagai proses resiliensi yang dialami oleh jurnalis $68 \mathrm{H}$, sumber daya apa saja yang berpengaruh pada proses resiliensi tersebut serta perubahan-perubahan perilaku apa saja yang terjadi pasca menghadapi tantangan yang berkontribusi pada penguatan resiliensi mereka di masa mendatang. 


\section{A. Proses Resiliensi}

Dari analisis yang dilakukan terhadap hasil wawancara, ditemukan bahwa proses yang dijalani oleh jurnalis $68 \mathrm{H}$ dapat dibagi ke dalam tahap-tahap berikut ini.

1. Melakukan estimasi terhadap tingkat tantangan yang mereka hadapi

Ketika paket bom buku diketahui diterima oleh Radio $68 \mathrm{H}$, maka saat itu kelima jurnalis $68 \mathrm{H}$ yang diwawancara menjalani proses resiliensi di mana ada tantangan yang datang menghampiri mereka. Ketika tantangan tersebut terjadi, mereka melakukan estimasi terhadap tingkat tantangan yang mereka hadapi.

Bercermin dari peristiwa ledakan bom, tidak ada seorang pun dari mereka mengira bahwa bom tersebut sungguh-sungguh nyata. CD menjelaskan mengapa ia tidak memberikan perhatian serius pada paket bom buku karena tanda-tanda pada paket dipandang jauh dari serius judul buku "kampungan", isi surat yang "aneh" serta identitas penulis dan pengirim paket tak jelas. Ia juga menjelaskan bahwa tindakan polisi yakni mengguyur air untuk menjinakkan bom juga membuat dirinya salah menilai tingkat ancaman paket tersebut.

Menurut AW dan $\mathrm{HH}$, ancaman dan intimidasi yang kerap diterima oleh Radio $68 \mathrm{H}$ selama ini membuat mereka mengira ini semua hanya olok-olok. AW juga menyebutkan bahwa dirinya menjadi "imun" karena sering menerima ancaman kosong. Hal ini juga tidak dapat dilepaskan dari pengalaman bersama para jurnalis Radio 68H baik sejak terlibat gerakan pro Reformasi di tahun 1998 dalam menggulingkan Soeharto dan ketika menghadapi ancaman FPI di tahun 2005.

SO dan HH berpendapat bahwa peristiwa gerakan reformasi tahun 1998 membuat mereka lebih memahami karakter manusia dalam situasi darurat. Reformasi 1998 juga memperkaya mereka dengan keterampilan dan pengetahuan tentang dinamika gerakan sosial dalam demokrasi. SO juga menyebutkan bahwa pengalaman ini membantu dirinya memahami mengapa di tahun 2005, FPI mengerahkan massanya untuk menyerang $68 \mathrm{H}$.

Di tahun 1998, kita sebetulnya sama saja dengan FPI. Dulu, barangkali kita tidak terlalu berbeda dengan mereka (catatan: ia menyampaikan hal ini sambil tersenyum).

Bagi AW, hal ini juga penting. Meskipun sampai sekarang ia masih ingat wajah-wajah mengancam dari anggota-anggota FPI, ia juga ingat bahwa peristiwa tersebut berhasil diatasi dan komunitas Utan Kayu menjadi kuat sebagai satu kesatuan. Hal ini pun penting bagi $C D$ yang ketika itu berada di belakang mikrofon dan menyiarkan ajakan mendukung kebebasan berekspresi.

Dapat dilihat bahwa jurnalis Radio $68 \mathrm{H}$ menggunakan pengalaman masa lalu sebagai referensi dalam menimbang tingkat ancaman yang mereka hadapi. Keberhasilan mereka mengatasi tantangan di masa lalu membuat mereka kurang akurat dalam mengidentifikasi tingkat ancaman secara akurat. Di sisi lain, pengalaman tersebut ini bermakna penting karena ketika itu mereka berhasil mengatasi tantangan. Resiliensi di masa lalu ini mewarnai tahap pertama dari proses resiliensi yang mereka jalani bertahun-tahun kemudian. 2. Merasakan sederetan respon yang muncul segera pada saat tantangan terjadi

Dari hasil analisis wawancara, diidentifikasi bahwa HH sempat tertegun selama beberapa detik saat bom tersebut meledak kemudian sontak merasa sangat marah dan merasakan adanya dorongan yang besar untuk melawan balik. Hal ini HH ungkapkan sebagai berikut:

Kita harus menunjukkan sikap. Kita harus mengutuk ini. Kita harus melawan.

Bercermin pada pernyataan yang ia ungkapkan ini, HH merasa respon tersebut ia rasakan karena selama ini dirinya meyakini bahwa Radio $68 \mathrm{H}$ selama ini sudah mempromosikan sikap anti kekerasan, 
membuka diri untuk melakukan dialog serta tunduk pada kode etik jurnalistik. Kemarahan HH merupakan bentuk ungkapan bahwa dirinya tidak bisa menerima situasi ini.

Subjek lain yaitu RH merasa panik, sebagaimana ia ungkapkan dalam pernyataan berikut ini.

Saya merasa marah karena tidak ada koordinasi kacau. Semua orang lari ke sana kemari. It was a mess, a big mess (ini semua berantakan, sungguh-sungguh berantakan). Beberapa menit yang lalu, bos saya yang saya sungguh-sungguh percayai berkata bahwa it was no big deal (ini bukan hal serius).

[...] Di mana saya mesti merasa aman sekarang? Saya pikir dari semua tempat di Indonesia, saya akan merasa aman di sini. Tetapi ternyata tidak.

Pada saat terjadinya ledakan bom buku, $\mathrm{CD}$ dan AW justru mengaku mereka tak merasakan perasaan takut ataupun panik pada saat mereka melaporkan dan memproduksi Buletin Sore. CD menyebut bahwa kepalanya "penuh" tentang apa yang harus ia lakukan selanjutnya sedangkan AW merasa seolah-olah ia mati rasa.

Dapat dilihat bahwa sementara terdapat subjek penelitian yang merasakan kemarahan dan kepanikan, ada pula yang justru 'mati rasa.' Respon-respon seperti inilah yang mereka rasakan ketika tantangan terjadi saat bom buku meledak.

3. Menguasai diri

Ketika paket tersebut meledak, CD kembali bekerja beberapa detik setelah ledakan bom terjadi dan tidak merasa panik. CD sendiri berada sekitar satu meter dari lokasi ledakan dan sebelumnya memotreti petugas kepolisian yang tengah menjinakkan bom. Karena posisinya yang sangat dekat dengan bom, maka rambutnya pun penuh serpih-serpihan debu akibat ledakan tersebut. Mengapa ia tidak merasa panik diungkapkan sebagai berikut:

Ini momennya. Ini eksklusif dan gue ada di situ sesederhana itu.

CD juga menambahkan bahwa karena dirinya bertanggung jawab mengelola situs Radio $68 \mathrm{H}$, ia menyadari bahwa ia harus banyak mengejar ketinggalan dibandingkan dengan para kompetitor dari media. Hal ini membuatnya menangkap urgensi dari peristiwa ledakan tersebut dan tidak membiarkan momen tersebut lepas dari genggaman. Dapat dilihat bahwa komitmen terhadap pekerjaan membantunya segera menguasai diri kemudian mengendalikan dirinya untuk kembali bekerja.

4. Fokus pada hal-hal yang penting, yang perlu dikerjakan dan yang bisa dikerjakan

Saat ledakan tersebut terjadi, AW yang saat itu tengah siaran dan mengelola Buletin Sore memilih untuk fokus pada urgensi untuk segera melaporkan kejadian ini melalui program berita yang ia kelola. AWlah yang kemudian menelepon CD yang memberikan reportasi dari tempat kejadian. AW menjelaskan hal ini sebagai berikut:

Kejadian ini di halaman rumah kita sendiri. Artinya kita jangan sampai ketinggalan, wawancara harus segera dilakukan, kita harus melakukan segala sesuatu lebih cepat dibandingkan dengan media lain.

Sementara itu, subjek penelitian lain yaitu SO fokus pada mitigasi bencana. Ia memberi serangkaian instruksi pada para petugas keamanan untuk segera membawa petugas kepolisian yang cedera ke rumah sakit. Dapat disimpulkan bahwa pada saat ledakan bom buku terjadi, maka subjek penelitian fokus pada pelaporan berita dan mitigasi bencana karena keduanya dianggap sebagai hal yang penting dan perlu untuk segera dikerjakan. 
5. Menjabarkan hal-hal yang menjadi prioritas kepada anggota komunitas maupun ke pihak-pihak di luar komunitas

Sekitar 1 jam setelah terjadinya ledakan bom buku, SO bersama dengan tim Radio 68H menggelar konferensi pers. Pesan ini diangkat dalam konferensi pers setelah ledakan bom adalah apresiasi pada polisi sekaligus keprihatinan atas kinerja institusi ini. Kesempatan ini juga digunakan SO untuk menekankan bahwa tak ada satupun, termasuk bom buku tersebut, yang dapat menghambat arus informasi. Dalam konferensi pers tersebut, SO menggunakan kata-kata 'mereka' untuk menyebut pihak pengirim bom, versus 'kami' untuk menyebut Radio $68 \mathrm{H}$ juga anggota Komunitas Utan Kayu lainnya termasuk JL. Dalam hal ini, yang SO maksud sebagai 'mereka' adalah pihak yang 'anti toleransi'.

Konferensi pers ini menjadi forum bagi Radio $68 \mathrm{H}$ untuk menyampaikan hal-hal yang menjadi prioritas mereka, yaitu membela kebebasan informasi dengan cara terus beroperasi menyiarkan berita. Konferensi pers tersebut merupakan wadah untuk menegaskan hal tersebut secara eksplisit pada anggota komunitas maupun pihak-pihak di luar komunitas. Subjek-subjek penelitian lain yaitu AW dan CD berpendapat bahwa konferensi pers tersebut bermakna bagi Komunitas Utan Kayu. Hal tersebut karena konferensi pers tersebut membantu membangun semangat senasib sepenanggungan.

6. Melakukan normalisasi dengan mengembalikan rutinitas

Radio $68 \mathrm{H}$ terus melanjutkan operasi sekalipun terjadi ledakan bom. Artinya pada saat polisi melakukan pemeriksaan terhadap saksi-saksi, jurnalis $68 \mathrm{H}$ kembali ke meja kerja dan melanjutkan tugas-tugas mereka.

Mengenai $68 \mathrm{H}$ yang langsung kembali beroperasi, AW memandang hal tersebut sebagai keputusan yang tepat. Ia berpendapat bahwa jika Radio $68 \mathrm{H}$ tidak kembali beroperasi, mereka justru tak tahu apa yang akan terjadi kemudian. Tentang hal ini CD juga mengungkapkan pendapat serupa.

Karena kita langsung balik kerja, semua orang kembali ke rutinitas masing-masing. Semua kembali seperti hari biasa. Kalau tidak, mungkin kita semua malah breakdown dan berantakan. [...] Ya, gue ngga tau sih [apa yang orang lain rasakan]. Gue ngga nanya. Yang penting kita semua baik-baik saja.

Dapat disimpulkan bahwa subjek-subjek penelitian melihat tahap normalisasi ini membuat mereka merasa bahwa situasi kembali seperti biasa. Hal ini berdampak pada proses resiliensi yang mereka jalani dalam menghadapi tantangan, terutama kondisi pasca ledakan.

Di sisi lain, salah satu subjek penelitian yaitu RH memiliki pendapat berbeda. RH mengajukan contoh di Burma/Myanmar, di mana para jurnalis pergi ke luar dari negara tersebut dan membuat berita-berita untuk disiarkan kembali ke dalam negara mereka. Ia berpendapat ada banyak cara yang lebih cerdas untuk memperjuangkan kebebasan berekspresi. Ia juga mempertanyakan apakah langsung kembali bekerja berarti menolak untuk menyerah.

Kalau terus bekerja berarti tidak menyerah. Oke. Tapi kalau kemudian kamu mati karena kamu terus bekerja, kita kan jadi tidak bisa terus berjuang?

7. Melakukan penguatan kelompok

Salah satu subjek penelitian yaitu HH mengungkapkan bahwa teman-teman mereka, termasuk para kolega dari media lain datang ke Radio $68 \mathrm{H}$ menunjukkan dukungan mereka. Dukungan dari jejaring sosial mereka penting bagi AW, CD dan $\mathrm{HH}$. AW juga memandang dukungan dari para kolega dan manajemen kantor sebagai hal yang berarti karena keluarga tinggal jauh dari dirinya. CD menegaskan bahwa karena suaminya, yang bekerja satu kantor, tetap tenang dan juga kembali bekerja, ia pun segera kembali tenang.

Selain dukungan dari rekan kerja, sokongan dari keluarga juga penting bagi HH. Ia menyebutkan bahwa istri dan anak-anaknya bersikap tenang dan mendukung keputusannya untuk terus bekerja. $\mathrm{RH}$ menyebut bahwa surat elektronik dan telepon dari koresponden Asia Calling di luar negeri, termasuk dari Filipina, Pakistan, Afghanistan dan Burma/Myanmar negara-negara yang selama ini dianggap sebagai ‘daerah berbahaya' bagi para jurnalis sangat berarti baginya. 
Keesokan harinya, Radio $68 \mathrm{H}$ mengumpulkan seluruh personil dengan tujuan memberikan penguatan kelompok (regrouping). HH memberikan penjelasan mengapa Radio 68H melakukan hal ini:

Jika kita tidak mengadakan pertemuan pagi sehari setelah kejadian, barangkali akan terjadi demoralisasi. Penting bagi kita untuk memberikan dukungan buat semua.

Dalam kesempatan ini, SO memberikan arahannya yaitu sebagai berikut:

Kita terus bekerja karena kita tidak boleh menyerah. Serangan ini merupakan bukti bahwa komunitas ini memperjuangkan sesuatu yang benar sesuatu yang layak untuk diperjuangkan: kebebasan berekspresi. [...]. Bersama-sama kita kuat. Kita tidak akan pernah menyerah.

Semua subjek sepakat bahwa penguatan kelompok keesokan hari setelah bom memiliki makna yang penting. CD mengungkapkan pendapatnya sebagai berikut:

Kita semua ada di situ, bukan cuma jurnalis, tetapi mereka yang bukan jurnalis juga ada di situ. [...]

Saat itu, gue merasa gue punya temen. Gue ngga sendirian. Gue punya temen yang bareng-bareng sama gue. Gue merasa semangat gue muncul lagi.

Subjek lain yaitu RH menyadari dirinya menjadi tenang saat HH dan SO minta maaf kepada semua orang. AW melihat cara SO berbicara "sangat menenangkan" sesuatu yang juga diperkuat oleh CD yang menyatakan bahwa SO terdengar "positif dan optimis."

SO mengajak mereka agar tidak mengolok-olok polisi, karena sekalipun terjadi kesalahan prosedur, tangan yang hilang tak akan pernah bisa tergantikan. Radio $68 \mathrm{H}$ kemudian mengumpulkan donasi untuk petugas kepolisian tersebut, langkah yang dinilai $\mathrm{CD}$ positif. SO menambahkan bahwa ia memberi kesempatan kepada semua personil untuk menyumbangkan gagasan dan berbagi informasi tentang bagaimana keamanan seharusnya diperkuat.

Dalam kesempatan tersebut, $\mathrm{HH}$ memilih gaya komunikasi yang lebih santai dan diwarnai senda gurau dalam pertemuan tersebut. Menurut $\mathrm{HH}$, gaya ekspresi seperti ini merupakan pilihan yang sengaja diambil oleh mereka.

Karena kami punya posisi manajemen, kami tidak boleh panik. Kami boleh marah, tetapi jangan sampai kelihatan panik. Kalaupun panik, itu disimpan di dalam hati, kami tidak boleh menunjukkannya.

[...]. Barangkali ini memang kutukan kami [catatan: ia menyampaikan hal ini dengan berkelakar].

Dapat dilihat bahwa subjek-subjek penelitian sepakat bahwa tahap penguatan kelompok ini penting bagi proses resiliensi mereka. Forum pertemuan ini berdampak pada kemampuan jurnalis $68 \mathrm{H}$ untuk bangkit kembali. Pertemuan ini juga merupakan wujud dari keputusan kepemimpinan (leadership) yang ada di organisasi tersebut.

8. Melakukan penguatan kapasitas

Setelah melakukan penguatan kelompok, HH melakukan langkah-langkah agar terus mempertahankan resiliensinya. HH melakukan kompartementalisasi ia hanya fokus pada hal-hal yang bisa ia tangani. Ia memilih untuk tidak mengangkat telepon dari nomor-nomor asing yang tak terdaftar dalam daftar kontak telepon genggamnya. Dengan mengisolasi diri dari gangguan-gangguan yang tak perlu, ia mengarahkan energinya pada hal-hal yang bisa ia tangani termasuk menghadapi respon orangorang tentang bom tersebut.

Selain itu, SO juga mengaku menghindar dari interogasi polisi sekalipun ia termasuk salah satu saksi mata yang perlu diambil keterangannya. Hal ini karena urusan dengan polisi ia anggap berpotensi menimbulkan kegusaran yang tak sanggup ia tangani. 
Subjek lain, RH, terus melanjutkan pekerjaan. Pekerjaan yang dilakukan oleh RH ini mencakup mewawancarai CD sebagai saksi mata ledakan bom untuk program Asia Calling. Bagi CD, pengalamannya diwawancara memunculkan pemikiran tentang tindakannya, yaitu sebagai berikut:

Gue jadi mulai berpikir 'What was I thinking? Gue itu kok bisa begitu?' [...] Gue punya keluarga. Anak gue nungguin di rumah [...]. Pas kejadian, gue tuh cuma mikir bahwa ini mesti dikerjain, itu mesti dikerjain. [...] Baru belakangan gue nyadar bahwa gue itu beruntung banget. Untung nggak ada paku di bom itu. Untung nggak ada bom susulan abis kejadian.

Bagi RH, proses wawancara CD pun ikut memberikan efek pemulihan (therapeutic) pada dirinya. RH menjelaskan pendapatnya sebagai berikut:

To listen to her story (bisa mendengar ceritanya), bisa tanya dan mendapat jawaban, bisa dapat informasi membuat saya merasa lebih kuat. Before, I was so confused (sebelumnya saya merasa sangat bingung).

Di sisi lain, AW menjelaskan proses yang berlangsung pada dirinya. AW mengaku bahwa keputusan $\mathrm{HH}$ menunjuk dirinya sebagai juru bicara $68 \mathrm{H}$ ternyata berdampak padanya. AW mengaku bahwa di harihari tersebut, ia merasa sangat lelah dan kehabisan tenaga sampai satu minggu setelah peristiwa ledakan tersebut. Ia menjelaskan pengalamannya lebih lanjut seperti di bawah ini:

Saya harus menjawab telepon yang tak pernah berhenti berbunyi. Saya harus mengulang hal yang sama terus-menerus. Saya harus mengangkat telepon di pagi hari dari nomor yang tidak saya kenali dan di ujung sana seseorang berkata, "Yang kirim bom itu saya," kemudian ia tertawa dan mematikan telepon. [...] Saya harus ada di kantor polisi untuk menjawab pertanyaan. Selama ini saya punya pandangan bahwa dipanggil ke kantor polisi berarti kita melakukan kejahatan dan saya ada di situ, di kantor polisi, menjawab pertanyaan-pertanyaan. [...] Beberapa orang bercanda dengan bilang bahwa saya jadi orang terkenal muncul di televisi, jadi selebritas dan sebagainya. Awalnya saya merasa jengkel dengan komentar-komentar seperti itu. Kalau saya bisa memilih, saya tidak akan mau berada dalam posisi seperti ini. Tetapi ya sudahlah, saya biarkan saja.

Beberapa hari setelah ledakan bom, AW mengaku merasa letih. Subjek lain yakni CD mendadak terbangun di satu malam setelah mendengar suara keras mengira itu bunyi bom. Ia juga mendatangi dokter spesialis THT untuk memeriksakan pendengarannya yang sementara sedikit terganggu karena posisinya yang dekat dengan bom yang meledak. HH menjadi lebih waspada ketika ia melihat wajah-wajah asing di Utan Kayu. Selain etos dan semangat kerjanya menurun, RH mengalami kesulitan tidur dan mimpi buruk akibat gambaran polisi yang cedera tak bisa ia hapuskan dari ingatan.

Namun, mereka semua menyebut bahwa mereka perlahan-lahan merasa lebih baik seiring dengan perjalanan waktu. Dalam wawancara, RH mengaku sudah cukup lama tidak memikirkan kejadian tersebut. CD juga menjelaskan bahwa sampai saat ini ia masih memandang Utan Kayu sebagai tempat yang aman bagi dirinya. AW memiliki pandangan tersendiri tentang hal ini.

Saya pernah berpikir, orang-orang yang bekerja di tempat lain, misalnya pabrik sepatu, tentunya punya kehidupan yang jauh lebih sederhana dibandingkan saya. Barangkali memang hidup jauh lebih simpel kalau saya memilih profesi lain. Tetapi saya juga ingat perkataan teman saya pekerjaan ini itu seperti candu, kita mungkin kadang-kadang kepingin keluar, tetapi kenyataannya kita tetap bertahan. [...]. Selain itu, bekerja di sini itu lebih dari sekadar menjadi jurnalis. Kita memperjuangkan idealisme - toleransi, pluralisme dan sebagainya. Berbeda dengan mereka yang bekerja untuk TV One atau Metro TV [catatan: televisi swasta ini dimiliki oleh figur yang memiliki kedekatan dengan politik], 
di mana jurnalis memilih untuk tidak melihat hal-hal yang dilakukan oleh si pemilik. Di sini, saya merasa saya menjadi bagian dari sesuatu yang lebih besar. Hal ini membuat saya merasa lebih kuat.

RH memahami bahwa jurnalis $68 \mathrm{H}$ memandang bom tersebut sebagai ancaman atas nilai-nilai yang penting bagi mereka. Tetapi ia menyoroti adanya berbagai kemungkinan bahwa bom ini disebabkan oleh faktor-faktor lain yang memang belum diketahui.

I want to believe that too, things become easier to comprehend then. (Saya ingin bisa percaya juga pada pendapat tersebut, jika pendapat itu benar, semua menjadi lebih mudah untuk dicerna.)

RH mengaku bahwa pandangannya yang berbeda barangkali disebabkan oleh perbedaan budaya karena dirinya warga negara Australia. Di antara semua subjek yang diwawancarai, ia adalah satu-satunya yang berteriak-teriak saat kejadian bom meledak, yang panik dan mengaku ketakutan. RH menjelaskan bahwa perbedaan standar dan pandangan tentang kehidupan boleh jadi mempengaruhi perilakunya. Di Indonesia, menurut pendapatnya, ada tingkat toleransi yang lebih tinggi terhadap tantangan serta akuntabilitas yang rendah.

Dari analisis yang dilakukan terhadap keseluruhan delapan tahap yang diidentifikasi berdasarkan analisis atas proses resiliensi, tampak bahwa para subjek berpendapat penguatan kelompok merupakan tahap yang paling penting bagi proses resiliensi mereka. Tahap inilah yang membuat mereka secara nyata merasa bahwa mereka mampu mengatasi tantangan yang tengah mereka hadapi bersama-sama sebagai komunitas.

\section{B. Sumber Daya (Resources) yang Mendukung Proses Resiliensi}

Bagi para subjek dari penelitian ini, dapat dilihat bahwa ada beberapa hal yang mereka anggap sebagai sumber daya (resources) bagi mereka.

Ketika ledakan terjadi, sumber daya utama adalah kewajiban profesi yakni menyediakan informasi kepada publik, membuka akses informasi dan menghasilkan karya-karya jurnalistik berkualitas (akurat, terperinci, terkini, eksklusif, dan lebih baik dibandingkan dengan para kompetitor). Sumber daya lain adalah pemahaman mereka akan urgensi dari peran meraka sebagai jurnalis. Mereka melihat bahwa mereka berperan sebagai pihak-pihak yang mempromosikan nilai-nilai toleransi, keberagaman, anti-kekerasan, demokrasi dan kebebasan berekspresi. Tak hanya itu, sumber daya lain yang penting dalam mendukung proses resiliensi mereka adalah adanya urgensi untuk mengecam pandangan yang mendukung sikap anti-toleransi dan kekerasan. Ketiga sumber daya tersebut tampak jelas pada tahap 1 sampai tahap 4.

Sumber-sumber daya tersebut berjalin berkelindan dengan kejernihan dalam mempersepsikan 'kita' $(68 \mathrm{H})$ versus 'kalian' (pihak pengirim paket bom buku) dan rasa percaya diri dalam mempersepsikan nilainilai yang dianggap 'benar' (menjunjung tinggi demokrasi, toleransi, anti kekerasan) versus 'salah' (anti demokrasi, anti toleransi dan kekerasan) yang dibangun secara segera dan tegas pada momen-momen pasca ledakan bom. Sumber-sumber daya tersebut tampak pada tahap 4 sampai tahap 7.

Rasa percaya diri dalam mempersepsikan identitas kolektif (siapa kita, apa yang kita lakukan, bagaimana kita melakukan apa yang kita lakukan, mengapa kita menghadapi tantangan ini dan lain sebagainya) ikut berkontribusi pada kejernihan tujuan, peran dan fungsi yang diambil dalam memutuskan apa yang perlu dilakukan saat ini dan apa yang sebaiknya dilakukan di hari-hari berikut. Hal-hal tersebut penting sebagai sumber daya dalam proses resiliensi mereka.

Kejernihan dalam mempersepsikan identitas kolektif ini berlandaskan pada kuatnya pengalaman bersama mereka, terutama ancaman FPI tahun 2005. Hal ini memberikan bekal keyakinan bahwa di masa 
lalu, mereka telah menghadapi tantangan seperti ini dan berhasil mereka atasi. Alhasil, mereka menyimpulkan bahwa dengan menunjukkan sikap yang sama, mereka pun akan mampu mengatasi tantangan yang ada pada saat ini.

Kejernihan persepsi ini juga didukung oleh kepemimpinan (leadership) yang ditunjukkan oleh para pembuat keputusan utama yang memiliki pemahaman yang jelas bahwa apa pun yang dilakukan dan dikatakan oleh pemimpin dalam situasi penuh tantangan seperti ini. Hal ini memiliki dampak ke seluruh organisasi. Di sisi lain, kepemimpinan ini berjalin berkelindan dengan kepengikutan (followership) atau kesediaan untuk ikut arahan dan dipimpin orang lain. Sumber daya ini tampak pada tahap 4 sampai 8.

Kepemimpinan seperti ini mengarahkan mereka ke rutinitas semula untuk secepatnya kembali bekerja. Keputusan-keputusan ini kemudian diperkuat oleh sumber-sumber daya lainnya yakni dukungan sosial rasa persaudaraan profesional (dukungan dari para kolega, telepon bernada simpati dari para koresponden, dan seterusnya), afirmasi dalam bentuk pernyataan solidaritas (dari sesama aktivis hak asasi manusia, dari elemen masyarakat sipil dan sebagainya) dan dukungan dari orang-orang terdekat (dari teman, pasangan hidup dan anak, dan sebagainya).

Sumber daya dukungan sosial ini tampak pada tahap 7 dalam penguatan kelompok dan membangun perasaan sebagai satu komunitas yang padu yakni komunitas jurnalis, pejuang kebebasan berekspresi dan komunitas Utan Kayu. Sumber daya ini secara kuat memberikan validasi terhadap keyakinan bahwa 'kita tidak sendiri', bahwa ada keyakinan terhadap misi bersama sekaligus keyakinan pada persepsi bahwa 'kita' adalah bagian dari orang-orang yang 'baik.'

\section{Perubahan Perilaku Berkat Peningkatan Kapasitas Resiliensi}

Pelatihan keamanan pasca bom berikut umpan balik sepanjang proses ini menyebabkan terjadinya perubahan-perubahan. Hal ini antara lain berupa penambahan petugas keamanan, relokasi fasilitas parkir, pembuatan jalur evaluasi, pembentukan CMT dan pelaksanaan latihan tanggap darurat.

Hal ini berdampak pada perubahan perilaku pada jurnalis $68 \mathrm{H}$ seperti misalnya cara mengidentifikasi paket mencurigakan dan lain sebagainya. Penguatan keamanan ini merupakan hal yang penting yang digarisbawahi oleh HH demi mencegah peristiwa ledakan bom ini jangan sampai terjadi lagi.

Terkait prosedur, pelatihan keamanan, pihak penasihat menyarankan agar menahan diri dalam menyebarluaskan hal-hal yang belum dikonfirmasi misalnya melalui penggunaan jejaring media sosial seperti Twitter dan Facebook. SO menyadari dilema seputar akses informasi ini berhenti menyebarluaskan informasi atau justru tetap melanjutkannya.

SO dan $\mathrm{HH}$ bertahan pada pendapat mereka yang berbeda dengan masukan penasihat keamanan untuk menghentikan siaran. SO berpegang pada prinsip bahwa $68 \mathrm{H}$ harus tetap mengudara. $\mathrm{HH}$ meyakini bahwa semakin informasi difasilitasi, semakin aman kondisi mereka. Perdebatan ini masih belum mencapai kesimpulan hingga sekarang dan belum ada standar prosedur operasional yang disusun sebagai pegangan terkait dengan hal ini.

SO menyadari adanya potensi tantangan di masa mendatang. Ada sekitar 150 sampai 200 orang yang bekerja untuk 5 organisasi di komunitas ini dan pindah ke tempat yang lebih aman merupakan pilihan yang tak terjangkau bagi mereka. Ia memastikan bahwa komunitas ini berupaya untuk mengurangi segala risiko yang mungkin terjadi, seraya tetap mempertahankan perjuangan mereka. 
Kemungkinan-kemungkinan yang dipertimbangkan oleh Radio $68 \mathrm{H}$ termasuk antara lain menggunakan layanan psikologi untuk memperkuat mereka dalam pemulihan pasca ledakan dan mempersiapkan diri menghadapi tantangan di masa mendatang.

\section{DISKUSI}

Penelitian ini bertujuan untuk menjawab bagaimana jurnalis-jurnalis $68 \mathrm{H}$ menjalani proses resilensi, sumber-sumber daya apa saja yang mereka gunakan dalam proses tersebut, dan perubahan-perubahan perilaku apa saja yang terjadi akibat pengalaman tersebut yang berdampak pada kemampuan mereka untuk menjadi resilien di masa mendatang.

Hasil penelitian menunjukkan berikut ini adalah proses yang dilalui para jurnalis $68 \mathrm{H}: 1)$ mereka menimbang tingkat tantangan yang mereka hadapi, 2) sementara tantangan tersebut tengah terjadi, mereka merasakan sederetan respon yang muncul spontan dan segera, 3) mereka menguasai diri kemudian mengambil kendali atas respon-respon tersebut, 4) mereka berfokus pada hal-hal yang penting, yang perlu dikerjakan dan yang bisa dikerjakan, 5) mereka menjabarkan prioritas-prioritas tersebut secara eksplisit dan jernih baik secara internal kepada anggota komunitas maupun ke pihak-pihak di luar komunitas, 6) mereka melakukan normalisasi dengan mengembalikan rutinitas normal, 7) mereka mengutamakan dukungan sosial lewat penguatan kelompok dan 8) mereka melakukan penguatan kapasitas demi mempertahankan resiliensi di masa mendatang. Dari proses yang tersebut di atas, tahap penguatan kelompok dinilai penting bagi resiliensi mereka.

Terkait dengan perubahan pada kemampuan mereka untuk menjadi resilien di masa mendatang, hal ini dapat ditemukan pada peningkatan kapasitas dalam bentuk pelatihan keamanan, CMT, pintu keluar darurat, standar prosedur operasional juga latihan tanggap darurat. Peningkatan kapasitas ini membentuk perasaan beruntung karena lolos dari marabahaya menjadi rasa kebersamaan bahwa mereka perlu mempertahankan dan melindungi komunitas ini. Perlu dicatat bahwa ada beberapa isu yang masih perlu disepakati karena ada sejumlah keterampilan dan pengetahuan baru yang diperoleh melalui kegiatan peningkatan kapasitas ini yang tidak sejalan dengan pengalaman bersama di masa lalu dan tidak dibagi secara setara oleh seluruh anggota komunitas.

Dibandingkan dengan penelitian-penelitian sebelumnya tentang jurnalis dan tantangan, seperti dalam McMahon \& McLelland (2008), Feinstein (2006) dan Coté \& Simpson (2000), kajian-kajian tentang jurnalis dengan trauma yang lebih banyak dibandingkan dengan kajian yang melihat jurnalis dari kacamata resiliensi. Di sisi lain, literatur yang tersedia memandang jurnalis sebagai individual dan perspektif individualisme ini lazim ditemui di negara-negara maju di Barat.

Di sisi lain, dari kajian literatur yang dilakukan dalam proses penyusunan tulisan ini, belum banyak yang melihat jurnalisme dan resiliensi dari sudut pandang kolektivisme sebagai bagian dari komunitas yang dipersatukan oleh ruang-ruang geografis dan konseptual tentang misi dan nilai bersama. Penelitian ini berharap untuk bisa berkontribusi pada pemahaman tentang jurnalis sebagai komunitas dalam menghadapi tantangan bersama. Hal ini karena berbeda dengan perspektif individualisme ala Barat, sudut pandang kolektivisme ini lazimnya diasosiasikan dengan budaya Asia atau Timur. Sementara hal tersebut tidak dibahas dalam tulisan ini, penelitian lebih lanjut tentang identitas kolektif para jurnalis dalam proses resiliensi mereka nantinya akan dapat memberikan kontribusi pada temuan-temuan yang bersifat ulayat (indegenous). 


\section{SIMPULAN \& SARAN}

Penelitian ini membuka ruang eksplorasi tentang kekerasan dan ancaman yang dihadapi oleh para jurnalis dan proses resiliensi mereka. Eksplorasi ini perlu dipahami dalam konteks saat mengkaji jurnalis sebagai komunitas untuk melihat bagaimana identitas kolektif berkontribusi pada resiliensi. Hal ini memberi penegasan bahwa terminologi, pengukuran serta kebijakan yang selama ini digunakan untuk mendefinisikan resiliensi tidaklah bisa dilepaskan dari konteks sehingga perlu ada penelitian intensif tentang resiliensi yang dibangun untuk tiap konteks yang berbeda.

Terkait dengan konteks $68 \mathrm{H}$, ada isu-isu yang perlu digali dalam penelitian lebih lanjut. Dengan menyoroti proses resiliensi yang terjadi dalam konteks $68 \mathrm{H}$, perlu ada kajian lebih lanjut tentang pengalaman 'kebal' ('callousness') sebagaimana tampak pada turunnya tingkat kewaspadaan akibat pengalaman masa lalu. Kajian untuk melihat hal ini sebaiknya menggunakan dua perspektif: perspektif pengalaman berulangulang menghadapi intimidasi dan dari perspektif perbedaan budaya kerja dari profesi jurnalis itu sendiri.

Terkait dengan sumber daya yang mereka gunakan dalam proses resiliensi, perlu ada kajian lebih mendalam bagaimana sumber-sumber daya yang berbeda-beda tersebut dimaknai dan oleh masing-masing jurnalis; bagaimana Radio $68 \mathrm{H}$ mendudukkan sumber-sumber daya tersebut dalam skala prioritas dan memastikan agar sumber-sumber daya tersebut selalu tersedia setiap saat. Terkait dengan perubahan, perlu ada upaya untuk memastikan bahwa peningkatan kapasitas tersebut juga menjawab isu kesejahteraan psikologis.

\section{UCAPAN TERIMA KASIH}

Penulis mengucapkan terimakasih kepada Cinintya Dewi (Yayasan Pulih), juga pada Adriatik Ivanti, Sandriaf Alga, Syarifah Aljas Sylvia Abdullah, Veronica A.M. Kaihatu dan Yosephine Dian Indraswari (Program Studi Psikologi Universitas Pembangunan Jaya), dan Ignatius Haryanto (Lembaga Studi Pers dan Pembangunan) atas masukan yang diberikan sepanjang proses penulisan.

\section{DAFTAR PUSTAKA}

Coté,W. E. \& Simpson, R. (2000). Covering Violence: A Guide to Ethical Reporting About Victims and Trauma. Columbia University Press: New York.

Feinstein, A. (2006). Journalists Under Fire: The Psychological Hazards of Covering War. The John Hopkins University Press: Baltimore.

Goldstein, S. \& Brook, Robert B. 'Why Study Resilience?' (2006) in Goldstein, S \& Brook, Robert B (Ed.) Handbook of Resilience in Children. New York: Springer Science + Business Media, LLC.

Gow, K. and Paton, D. (Ed.). The Phoenix of Natural Disasters: Community Resilience. Nova Science Publishers: New York.

Helgason, T. R. (2008). Psychological Resilience: A Qualitative Exploration into Personal Meanings and Process. A Master of Arts Thesis submitted to Faculty of Graduate Studies of the University of Manitoba. 
Hill, D. T. (2011). Pers di Masa Orde Baru. (diterjemahkan oleh Soerjoatmodjo, G). Jakarta: Yayasan Obor Indonesia.

Reich, J. W., Zautra, A. J. \& Hall, J. S. (Ed.). (2010). Handbook of Adult Resilience. London: The Guildford Press.

Reissman, D. B., Klomp, R. W., Kent, A. T. \&Pfefferbaum, B. (2004). Exploring Psychological Resilience in the Face of Terrorism. Psychiatric Annals Vol 34(8), Aug 2004, 627-632.

Schilling, T. A. (2008). An Examination of Resilience Process in Context. Urban Review Volume 40: pp. 296-316. New York: Springer Science + Business Media, LLC.

\section{Internet}

Bambits378. (2011, 16 Maret). Bom buku utan kayu jakarta [Berkas video]. Diunduh pada tanggal 18 Mei 2011 dari http://www.youtube.com/watch?v=1OL9iCoM2vg\&feature=related.

Situs Utan Kayu diakses 17 Mei 2011 dari www.utankayu.org.

\section{Media Massa}

Pikiran Rakyat (2011) Liput Konflik Berpotensi Trauma diterbitkan tanggal 27 Februari.

The Jakarta Post. Utan Kayu Community Condemns Bombing. Terbit 15 Maret 2011.

The Jakarta Post. JIL, hard-liners sidestep confrontation. Terbit 6 Agustus 2011. 
